\title{
Ancient handbooks and Graeco-Egyptian collections of alchemical recipes
}

\author{
Matteo Martelli* \\ Department of Philosophy and Communication Studies, University of Bologna, Italy \\ *Corresponding author: Matteo Martelli, email: matteo.martelli@unibo.it
}

\begin{abstract}
A fluid terminology was used in antiquity to refer to scientific or philosophical writings that, in some respects, may be equated with what one would call today a handbook or manual. In particular, this paper will explore a group of treatises that may be counted as examples of ancient encheiridia, a Greek term that could mean 'hand-knife', 'handbook' and even 'napkin, towel'. All these meanings have something to tell us about the nature and the history of ancient encheiridia, some of which can be identified with well-known pieces of Graeco-Roman literature. However, the spectrum of ancient encheiridia can be further enlarged by exploring sources that are often neglected. After giving an upto-date overview of ancient 'handbooks', the article will discuss the term encheiridion in GraecoEgyptian alchemical literature. In fact, fresh textual investigations of the Syriac tradition of Zosimus of Panopolis point to the circulation of ancient recipe books that bore this title. On the one hand, this investigation will shed new light on the tradition of other important collections of alchemical recipes, such as the medieval Mappae clavicula. On the other, it will highlight some strategies that ancient alchemical authors developed in selecting, reorganizing and legitimizing earlier alchemical recipes.
\end{abstract}

Between the first and fifth centuries CE, several Greek and Latin authors made an effort to give comprehensive and, at the same time, concise accounts of different crafts and sciences, thus producing writings that, in different respects, may be compared with what one would call today a handbook or manual. A rich yet fluid terminology was, however, used to refer to these works, which were often marked with different labels serving either as titles or as short descriptions of their typology. The formal characteristics of ancient scientific literature have started to receive more systematic exploration in recent years, with scholars devoting much closer attention to its literary dimension. ${ }^{1}$ In a seminal study on the rhetoric of Graeco-Roman scientific discourse, Philip van der Eijk has convincingly argued that medical or philosophical writings do not seem to reflect a unified system of genres based on consistent classifications of their formal, rhetorical

1 See, e.g., Markus Asper, Griechische Wissenschaftstexte: Formen, Funktionen, Differenzierungsgeschichten, Stuttgart: Franz Steiner Verlag, 2007; Liba Taub, Science Writing in Greco-Roman Antiquity, Cambridge: Cambridge University Press, 2017.

(c) The Author(s), 2020. Published by Cambridge University Press on behalf of British Society for the History of Science. This is an Open Access article, distributed under the terms of the Creative Commons Attribution licence (http://creativecommons.org/ licenses/by/4.0/), which permits unrestricted re-use, distribution, and reproduction in any medium, provided the original work is properly cited. 
and stylistic features. ${ }^{2}$ Ancient authors often referred to their works by using and combining a fluid terminology, which included terms like: hypomnēma, 'note, memorandum', 'commentary'; syngramma, 'treatise'; technē, 'manual'; epitome, 'epitome'; encheiridion, 'handbook'; syntomè, synagōgēe, 'compendium'; synopsis, 'summary'; eisagōgēe, 'introduction'; didaskalia, 'teaching, instruction'.

Pliny the Elder (Natural History, praef. §24) and Aulus Gellius (Attic Nights, praef. §7) provide long lists of 'book titles' (inscriptiones), actually terms that refer metaphorically to the genres of ancient books rather than to their subject matters: one finds 'meadows' (leimōna) or 'torches' (lychnoi) next to more explicit titles such as 'problems' (problèmata) or 'instructions' (didaskalika). ${ }^{4}$ The only bodily metaphor recorded in these lists is encheiridion

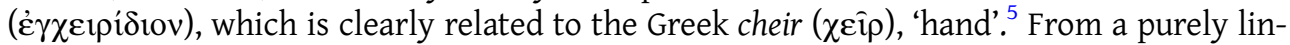
guistic point of view, this term represents the closest ancient cognate to modern words

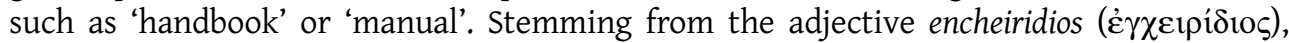
'hand-held, that fits into one's hands', this substantive could refer either to a 'hand-knife, dagger' or, along with its Latin transcription enchiridion, to a (hand)book. ${ }^{6}$

In its second meaning, the term encheiridion already occurs in the treatise On the Size of the Sun attributed to the Epicurean philosopher Demetrius Laco (second century BCE), where it is mentioned as the title of an Epicurean bybl(e)idion, a 'booklet' perhaps authored by Demetrius himself.' Unfortunately, Demetrius' handbook is lost, and only seven ancient writings explicitly defined as encheiridia have come to us. They pertain to different fields, in particular harmonics, metrics, mathematics, astrology and ethics (either pagan or Christian), and can be chronologically and geographically distributed as follows:

1 Encheiridion on Harmonics by the Neopythagorean philosopher Nicomachus of Gerasa (first-second century CE). Little is known about his life.

2 Encheiridion on Metres by the Alexandrian grammarian Hephaestion (second century $\mathrm{CE}$ ), who was appointed in Rome the teacher of the young prince Lucius Verus.

3 Encheiridion of Epictetus by Arrian (second century CE), pupil of Epictetus in Rome.

4 On Faith, Hope and Love by Augustine of Hippo (354-430 CE), which the author explicitly described as an enchiridion.

5 The Latin translation of the Sentences of Sextus, presented as an enchiridion by Rufinus (c.400 CE), a monk who spent his life in monastic communities between Aquileia, Jerusalem and Rome.

6 Encheiridion of Arithmetical Introduction by the Neoplatonic philosopher Domninus of Larissa (fifth century CE), active between Athens's Academy and his home town.

7 The Apotelesmatics by the astrologer Hephaestion of Thebes (fifth century CE), a compilation of earlier astrological texts that the author, perhaps active in Alexandria, labelled an encheiridion.

2 Philip J. van der Eijk, 'Towards a rhetoric of ancient scientific discourse: some formal characteristics of Greek medical and philosophical texts (Hippocratic Corpus, Aristotle)', in Egbert J. Bakker (ed.), Grammar as Interpretation: Greek Literature and its Linguistic Contexts, Leiden and New York: Brill, 1997, pp. 77-129.

3 Van der Eijk, op. cit. (2), pp. 89-91; Asper, op. cit. (1), pp. 45-54.

4 See Bianca-Jeanette Schröder, Titel und Text: Zur Entwicklung lateinischer Gedichtüberschriften. Mit Untersuchungen zu lateinischen Buchtiteln, Inhaltsverzeichnissen und anderen Gliederungsmitteln, Berlin and New York: De Gruyter 1999, pp. 49-60.

5 On the use of bodily metaphors as book titles in Chinese handbooks see Marta Hanson's paper in this issue.

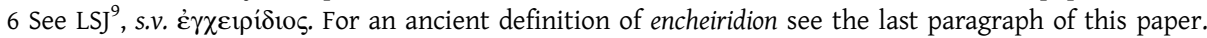

7 Costantina Romeo, 'Demetrio Lacone sulla grandezza del sole (PHerc. 1013)', Cronache ercolanesi (1979) 9, pp. 11-35. The attribution to Demetrius Laco has been questioned by Jonathan Barnes, 'The size of the sun in Antiquity', Acta Classica Universitatis Scientiarum Debrecensis (1989) 25, pp. 29-41. See also Enzo Puglia, 'L'“enchiridion” di Demetrio Lacone', Cronache ercolanesi (1986) 16, pp. 45-51. 
Despite differences in contents and purposes that will be discussed in the following pages, we can preliminarily observe that most encheiridia are short writings - a feature that is often stressed by ancient authors and separates their works from modern handbooks, in particular twentieth-century reference works in multiple volumes. ${ }^{8}$ Domninus' encheiridion, for instance, runs to about ten octavo printed pages in its most recent edition; ${ }^{9}$ Nicomachus' and Augustine's handbooks are respectively around thirty pages long in Jan's edition and around sixty pages long in Evans's edition. ${ }^{10}$ Hephaestion's Apotelesmatics, on the contrary, includes three books, a fact that might point to an important innovation in the development of this book type.

Both astrology and alchemy are less explored fields that were neglected by Broccia in his study on ancient encheiridia, mainly guided by lexical interests. ${ }^{11}$ I will devote the second part of this paper to Graeco-Egyptian alchemical literature, in which the term encheiridion seems to refer to recipe books collected in third- to fourth-century Egypt. This will allow me to expand the cluster of ancient encheiridia and to explore the flexibility of a label that was used across centuries to mark different writings: summarized versions of textbooks, mainly used as primers by beginner students of various technai (harmonics, mathematics and metrics); collections of ethical precepts and instructions, addressed to any Christian believer; reference works that any practitioner of astrology and alchemy was expected to have at his disposal.

\section{Ancient encheiridia: from music to astrology}

Nicomachus' handbook on musical theory, the Encheiridion on Harmonics, is opened by a preface where the author claims to have written this book in a hurry, while travelling, in order to meet the demand of an unnamed noblewoman: ${ }^{12}$ in this way, she could have at her disposal a memorandum (hypomnema) of the elements of harmonics. ${ }^{13}$ The expression recalls the three-book treatise Elements of Harmonics by the philosopher Aristoxenus (fourth century BCE): indeed, as nicely explained by Andrew Baker, Nicomachus' handbook unrolls 'an exposition of the simplest and most basic structures that Aristoxenus himself identifies, re-expressed and explicated in Pythagorean terms'. ${ }^{14}$ Nicomachus, for instance, opens his handbook with the Aristoxenian distinction between continuous and intervallic vocal movements (Chapter 2) and discusses definitions of key elements of music (e.g. notes, intervals, scales) in Chapter $12 .{ }^{15}$ Along with this technical information, more narrative sections deal with the relations between notes and planets (Chapter 3), Pythagoras' discovery of the eight-note scale (Chapters 5-6), and doctrines attributed to Plato and Philolaus (Chapters 8-9). Nicomachus wanted

8 See, in particular, Mathias Grote's paper in this issue.

9 Peter Riedlberger, Domninus of Larissa, Encheiridion and Spurious Works: Introduction, Critical Text, English Translation, and Commentary, Pisa and Rome: Fabrizio Serra Editore, 2013, p. 75.

$10 \mathrm{Karl}$ von Jan, Musici scriptores Graeci, Leipzig: Teubner, 1895, pp. 237-65; Ernest Evans's edition of Augustine's Encheiridion in vol. 46 of the Corpus Christianorum Series Latina, Turnhout: Brepols, 1969, pp. 49-114.

11 Giuseppe Broccia, Enchiridion: Per la storia di una denominazione libraria, Rome: Edizioni di storia e letteratura, 1979.

12 On this preface see Jason König, ‘Conventions of prefatory self-presentation in Galen's On the Order of My Own Books', in Christopher Gill, Tim Whitmarsh and John Wilkins (eds.), Galen and the World of Knowledge, Cambridge: Cambridge University Press, 2009, pp. 35-58.

13 Greek text in Jan, op. cit. (10), pp. 237-8. English translation in Andrew Baker, Greek Musical Writings, vol. 2: Harmonic and Acoustic Theory, Cambridge: Cambridge University Press, 1989, pp. 247-8. If not otherwise specified, all the translations of Greek, Latin and Syriac texts quoted in the paper are mine.

14 Baker, op. cit. (13), p. 246.

15 In Byzantine manuscripts Nicomachus' work is divided into twelve chapters, each introduced by a specific title. This division, however, seems to be a later innovation. See Asper, op. cit. (1), p. 262. 
to set out the capital points (kephalaia) of harmonics in simple form, without elaboration or complex demonstration, in order to write a concise account in a single book. Because of its concision, this summary (synopsis) could serve as an encheiridion that helped the noblewoman 'to recall herself of what is said and taught in outline [kata platos] in each section

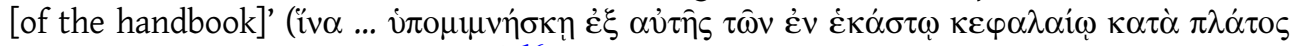

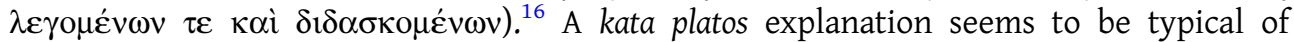
ancient 'summaries' (synopseis), as one can see, for instance, in the Summary on Pulses i.e. ancient diagnostic techniques based on the analysis and classification of pulses attributed to the physician Rufus of Ephesus (first-second century CE). At the end of various sections of his synopsis, the author claims to have dealt with the selected topic, such as the impact of age or fevers on pulses, in outline (kata platos). ${ }^{17}$ If the medical text (never labelled as an encheiridion) is based on earlier written works on the topic, Nicomachus' synopsis seems to follow the lectures that he had already given to the noblewoman. At the end of the preface, Nicomachus says,

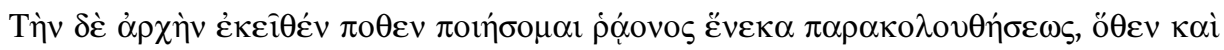

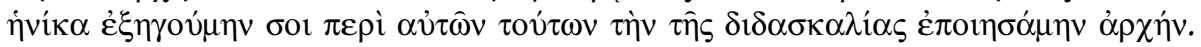

But now, to make my exposition easy to follow, I shall begin from the same place where I began my teaching when I was expounding these things to you in person. ${ }^{18}$

The encheiridion somehow replaces Nicomachus' oral teaching and serves as an aide-memoire for a student who has already been taught the capital points outlined in the book. As convincingly argued by Asper, the book mirrors the contents and order of the lectures that Nicomachus gave to the noblewoman: this might explain the mixed nature of his handbook, which combines technical notions with philosophical and historical discussions. ${ }^{19}$ This material sounded familiar to the woman, who could read through the book or linger over single sections that required more attention. Nicomachus himself occasionally guides the reader with cross references, and he specifies, in various passages, which topics have been left aside.

The author planned to deal with these topics in a more comprehensive work, namely an isagogic treatise (eisagōge $)$ in various books. ${ }^{20}$ At the end of his handbook, he tells the noblewoman that, gods willing, he will send her a 'a most thorough and altogether a most

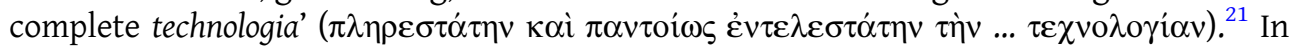
all likelihood, Nicomachus was never able to write such a treatise. The term technologia, however, deserves special attention. Frequently used by ancient grammarians, it refers to a systematic account of a given art (techne) , which, after providing a definition of this art, sets up its rules. ${ }^{22}$ While discussing the status of rhetoric, the Epicurean

16 Greek text in Jan, op. cit. (10), p. 248. Asper, op. cit. (1), p. 264, translates, 'du erinnerst dich an das, was ich in jedem Kapitel in größerer Ausführlichkeit gelehrt und dargestellt habe'. The use of present participles, however, is odd to refer back to what Nicomachus had already taught to the woman (it would rather refer to the actual content of the encheiridion); moreover, the comparison with other synopses (see above) confirms that the expression kata platos has here the usual meaning of 'loosely, in outline' (LSJ', s.v. $\pi \lambda \dot{\alpha} \tau o \varsigma)$.

17 Greek text edited in Charles Daremberg and Emile Ruelle, Oeuvres de Rufus d'Ephèse, Paris: Imprimerie nationale, 1879, pp. 219-32, esp. 225 (1. 9), 226 (1. 9).

18 Greek text in Jan, op. cit. (10), p. 238, 11. 12-15; translation (slightly modified) by Baker, op. cit. (13), p. 248.

19 Asper, op. cit. (1), p. 264.

20 See Jan, op. cit. (10), p. 238.

21 See Jan, op. cit. (10), p. 265 (Greek text); Baker, op. cit. (13), p. 269 (translation).

22 These rules are often referred to with the term $\tau \dot{\alpha} \tau \varepsilon \chi v o \lambda o \gamma o v ́ \mu \varepsilon v \alpha$, from $\tau \varepsilon \chi v o \lambda o \gamma \varepsilon$, 'to prescribe as a rule of art' $\left(\mathrm{LSJ}^{9}\right)$. On this type of grammatical treatise (also defined $\tau \dot{\varepsilon} \chi v \eta$-type treatises) see Stefano Valente, 'Typology of grammatical treatises', in Franco Montanari, Stephanos Matthaios and Antonios Rengakos (eds.), Brill's Companion to Ancient Greek Scholarship, 2 vols., Leiden and Boston: Brill, 2015, vol. 1, pp. 600-11. 
philosopher Philodemus (first century BCE) often refers to technologiai used in schools run by sophists: they provided instructions that, after being properly learned and practised, allowed (gifted) students to compose beautiful discourses. ${ }^{23}$ The term also occurs in medical treatises. In Book 48 of Oribasius' Medical Collections (fourth century CE), the term technologia marks a section that lists different types of bandage (both 'simple' and 'complex') and explains the names and uses of each type. ${ }^{24}$ A clear effort to classify and plainly unfold the technical aspects (and nomenclature) of a given art seems typical of a technologia, a term that Nicomachus, too, used to describe his own Introduction to Arithmetic. ${ }^{25}$ The work is a textbook for beginner students, which gives a well-structured account of arithmetic (or theory of numbers), from its definition (and relationship with other disciplines, in particular geometry, music and astronomy) to the discussion of its main elements, such as odd and even numbers with their main subspecies; prime, perfect and figurate numbers; means and proportions. The style is discursive and avoids axiomatic-deductive proofs, each definition being clarified with examples that can help students to visualize abstract concepts in simple sets of numbers. Diagrams and multiplication tables complete the textbook. ${ }^{26}$ The Introduction was successful, and it was paraphrased and commented on by later philosophers; it was also used by Domninus of Larissa (fifth century CE) as the main basis for his Encheiridion of Arithmetical Introduction. This work, indeed, has been recently described as a 'pocketbook version' of Nicomachus' Introduction to Arithmetic, since it follows the same structure of the earlier textbook. ${ }^{27}$ However, Domninus does not define arithmetic as a discipline and, for each basic notion, he only provides a single condensed definition (taken from Nicomachus as well as from other sources, such as the seventh book of Euclid's Elements), along with a few elementary examples. Sometimes he deals with more advanced notions, such as proportions, a topic that, as he admits $(\$ 35),{ }^{28}$ certainly requires a specific technologia. Indeed, in his Introduction, Nicomachus devoted many pages to this subject (Chapters 21-9), providing detailed discussions for proportions of various kinds. ${ }^{29}$ Domninus, on the contrary, gives preliminary definitions of the three main types (i.e. arithmetic, geometric and harmonic proportions), condensed in a few short paragraphs (\$\$36-40), which fit on a single page of Riedlberger's edition. Like Nicomachus' isagogic work, Domninus' encheiridion, in all likelihood, was used in schools. It served as a mathematical primer for students in late antique Neoplatonic schools: their teacher summarized in it those elementary notions that they were expected to internalize in order to fully benefit from his lectures. ${ }^{30}$

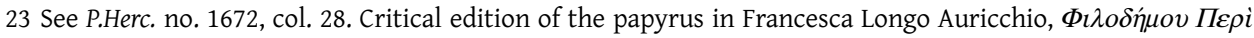
$\dot{\rho} \eta \tau o \rho \imath \kappa \hat{\eta}$, libri primus et secundus, Naples: Giannini, 1977, pp. 163-277, 235. The fragment belongs to second book of Philodemus' On Rhetoric, where we find many occurrences of the term technologia, consistently translated as 'technical manual' by Clive Chandler, Philodemus, On Rhetoric, Books 1 and 2: Translation and Exegetical Essays, New York: Routledge, 2006, pp. 44-57, 52 (translation of col. 28).

24 Johannes Raeder, Oribasii Collectionum medicarum reliquiae, libri XXIV-XXV. XLIII-XLVIII, Leipzig and Berlin: Teubner (CMG VI 2, 1), 1932, pp. 273-4. See also the short work On Bandages attributed to Galen in Karl G. Kühn, Claudii Galeni opera omnia, vol. 18a, Leipzig: Knobloch, 1829, pp. 768-827, 773-4.

25 Jaap Mansfeld, Prolegomena Mathematica: From Apollonius of Perga to Late Neoplatonism, Leiden and Boston: Brill, 1998, pp. 82-7.

26 See Thomas Heath, A History of Greek Mathematics, vol. 1, From Thales to Euclid, Oxford: Clarendon Press, 1921, pp. 97-112; Serafina Cuomo, Ancient Mathematics, London and New York: Routledge, pp. 181-3; Asper, op. cit. (1), pp. 282-92.

27 See Riedlberger, op. cit. (9), p. 75.

28 On the philological problems raised by this section see Riedlberger, op. cit. (9), pp. 174-9.

29 Richard G. Hoche, Nichomachi Geraseni Pythagorei Introductionis arithmeticae libri II, Leipzig: Teubner, 1866, pp. 119-46.

30 See Asper, op. cit. (1), pp. 242-3; Riedlberger, op. cit. (9), p. 76. 
Similar features characterize the handbook on metres by the Alexandrian grammarian Hephaestion (second century CE). His encheiridion provides no definition of the metrical art and its main element, namely the 'metre', a concept that, according to Hephaestion, would not have been grasped by inexperienced students. ${ }^{31}$ Hephaestion pragmatically starts his account from the definitions of long and short syllables, the building elements of the 'feet' (i.e. specific sequences of syllables), which, combined according to specific patterns, form the nine metres that he describes individually. The author, indeed, wrote his handbook for beginners. Each case is elucidated by a series of examples taken from lyric and comic poetry, which were easy and appropriate for school exercises. On the contrary, tragedy and choral poetry, being more difficult, are systematically avoided by Hephaestion. ${ }^{32}$

Like Domninus, Hephaestion, too, based his own encheiridion on larger treatises. Relevant information on this point is provided by later scholars who commented on his handbook. This hermeneutical activity left its mark in Byzantine manuscripts, which preserve an extensive body of scholia and exegetical notes. ${ }^{33}$ In particular, the Byzantine teacher and grammarian George Choeroboscus (eighth-ninth centuries $\mathrm{CE}$ ) specifies that the handbook was the result of careful textual work done by Hephaestion himself, who progressively summarized a larger treatise in forty-eight books that he wrote on metres: he first reduced this extensive treatise to eleven books, then to three books, and finally to only one book, namely the encheiridion itself. ${ }^{34}$

In a way, ancient encheiridia were types of summary, in some cases self-epitomes, when the author of a handbook abbreviated his own works. ${ }^{35}$ Arrian (first-second centuries CE), a pupil of the Stoic philosopher Epictetus, took notes of the lectures given by his master, and collected them in a work commonly referred to as Discourses, in four books. This collection was summarized by Arrian himself into the well-known Encheiridion, a short handbook of Stoic ethics. In his prefatory letter addressed to Messalenus - only partially preserved in Simplicius' Commentary on the Encheiridion (sixth century CE) - Arrian explains that he has selected from the Discourses the principal and most necessary elements of this philosophy, which are most likely to move the souls of the readers' ( $\tau \dot{\alpha}$

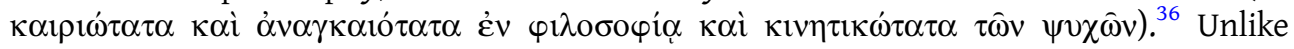
Nicomachus' Encheiridion, based on the oral teaching of its author, the Stoic handbook drew on Arrian's previous transcriptions of the lectures given by Epictetus. The collected precepts were addressed to those who followed these lectures, either students attending the classes or students who, after leaving school, wanted to have an easily accessible memorandum of what they had learned. ${ }^{37}$

Self-epitomes are well known in medicine as well. Oribasius, for instance, doctor of the Emperor Julian, authored a seventy-volume encyclopedia usually referred to as Medical Collections. This large work, which collected the best of what the most accurate doctors

31 See Longinus' commentary on Hephaestion's handbook: Maximilian Consbruch, Hephaestionis Enchiridion cum commentariis veteribus, Leipzig: Teubner, 1906, p. 86, 11. 1-5; Johannes M. van Ophuijsen, Hephaestion on Metre: A Translation and Commentary, Leiden and New York: Brill, 1987, pp. 11-12.

32 Stephanos Matthaios, ‘Greek scholarship in the imperial era and late antiquity', in Montanari, Matthaios and Rengakos, op. cit. (22), pp. 184-296, 274-5.

33 Eleanor Dickey, Ancient Greek Scholarship, Oxford: Oxford University Press, 2007, pp. 104-5.

34 Consbruch, op. cit. (31), p. 181.

35 Markus Dubischar, 'Preserved knowledge: summaries and compilations', in Martin Hose and David Schenker (eds.), A Companion to Greek Literature, Malden, MA and Oxford: Wiley Blackwell, 2016, pp. 427-40.

36 See Gerard Boter, 'From discourses to handbook: the Encheiridion of Epictetus as a practical guide to life', in Marco Formisano and Philip van der Eijk (eds.), Knowledge, Text and Practice in Ancient Technical Writing, Cambridge: Cambridge University Press, 2017, pp. 163-99, 167.

37 Boter, op. cit. (36), pp. 181-3 (with further bibliography). 
wrote on the various parts of medicine, was abridged by Oribasius himself in two writings: (1) a Synopsis for his son Eustathius (a physician himself) in seven books; (2) a four-book work addressed to Eunapius, a rhetor and amateur physician. In the preface to the Synopsis, Oribasius claims to have abridged his Collections to produce a summary that physicians could carry along when travelling as a reminder of what is needed in practice. For this reason, Oribasius only included easily available medicines, which, unlike surgery (which required a high degree of expertise), could be handled by people with some medical experience. This feature is further emphasized in the preface to the books to Eunapius, where Oribasius claims to have only collected the most effective and simple remedies: even laypeople with limited medical experience could refer to these books and put the described therapies into practice when they were in the countryside, with no professional doctors available in the area. ${ }^{38}$ Neither summary was ever presented by Oribasius as an encheiridion, despite some similarities with the handbooks discussed above: they were summaries of larger works, which condensed in portable volumes the most useful and easily accessible elements of medicine. However, unlike ancient encheiridia, Oribasius' summaries are multi-volume works and do not have close links with school contexts: on the contrary, they appealed to a broader readership, including amateur physicians as well as laypeople with some experience and interest in medicine.

Similar features are also recognizable in some examples of fifth-century encheiridia, which do not stem from larger textbooks or lecture notes. After being appointed Bishop of Hippo, Augustine authored a short treatise On Faith, Hope and Love (c.421 CE) for a certain Laurentius, a man of some consequence (perhaps an administrative officer). Augustine was asked by letter to write an enchiridion that would explain how to worship God properly. The explanation was simple: God must be worshipped with faith, hope and love, and Augustine briefly explained these three pillars of Christian religion in a short book that served as an encheiridion, 'something that can be held in the hand, not just baggage for your bookshelf (quod manu possit astringi, non quod armaria possit onerare). ${ }^{39}$ Likewise, the monk Rufinus of Aquileia (c.400 CE) labelled his Latin translation of the Sentences of Sextus an enchiridion. The work is a compilation of ethical and religious sayings assembled by a second-century Christian author who reworked earlier pagan gnomologies. ${ }^{40}$ In the framework of a larger effort to build a Latin library of Greek patristic works, ${ }^{41}$ Rufinus translated the Sentences at the request of the aristocratic woman Avita: she was looking for a book that, without being intellectually demanding, could be of great benefit to its reader (praef. 5-6). The Sentences perfectly met this demand, as the work was defined as an echeiridion in Greek or an anulus ('ring') in Latin: the whole book was so small that it could never leave Avita's hands, as an old precious ring that the woman always wanted to have on her finger (praef. $13-15) .{ }^{42}$ Each maxim was so clear and deep that the reading of a single line could suffice for the perfection of an entire life (praef. 10-11). Despite the private requests that Augustine and Rufinus mention in their prefaces, both authors had a broader audience in mind: by simply reading and rereading their handbooks, any well-educated Christian believer could learn the teaching

38 Philip van der Eijk, 'Principles and practices of compilation and abbreviation in the medical “Encyclopaedias” of late antiquity', in Marietta Horster and Christiane Reitz (eds.), Condensing Texts Condensed Texts, Stuttgart: Franz Steiner Verlag, 2010, pp. 519-54, 528-32.

39 See Albert Cook Outler, Augustine, Confessions and Enchiridion, Louisville: Westminster Press, 1955, p. 337.

40 Daniele Pevarello, The Sentences of Sextus and the Origins of Christian Ascetism, Tübingen: Mohr Siebeck, 2013, pp. 1-23; Henry Chadwick, The Sentences of Sextus: A Contribution to the History of Early Christian Ethics, Cambridge: Cambridge University Press, 1959, p. 138.

41 Catherine M. Chin, 'Rufinus of Aquileia and Alexandrian afterlife: translation as origenism', Journal of Early Christian Studies (2018), 18, pp. 617-47.

42 Latin text of Rufinus' preface in Chadwick, op. cit. (40), pp. 9-10; see Pevarello, op. cit. (40), p. 18. 
encapsulated in the portable books and put it into practice. These works served as vademecum that, in terms of physical format, could have been small booklets: in fact, the introduction in the fourth century CE of the codex format, which replaced papyrus rolls, made it possible to produce pocketbooks of reduced size. ${ }^{43}$

On the other hand, not every fifth-century encheiridion was a small, single book. The late antique astrologer Hephaestion of Thebes, in fact, used the term encheiridion to label a multi-volume astrological handbook (I praef. \$1). ${ }^{44}$ His Apotelesmatics (415 CE) are a three-book compendium of earlier authoritative sources on astrology, in particular Ptolemy's and Dorotheus of Sido's works. As Hephaestion points out at the end of the preface, his encheiridion was designed to be as understandable and useful as possible in the explanation it provided, with due conciseness (syntomia), of the apotelesmatic treatises (apotelesmatika syntagmata) of the ancients. From these treatises Hephaestion extracted those data that are more needed in practice. For instance, as for the 'powers' (dynameis) of the seven wandering stars, he provides a dry list that reads (I.2),

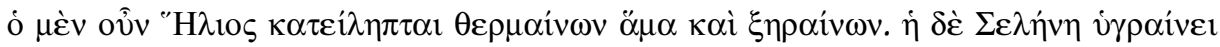

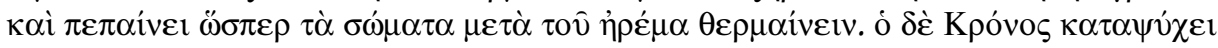

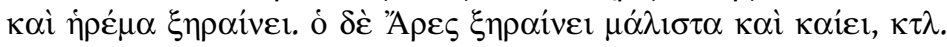

The sun is taken as heating and drying at the same time; the moon moistens and, in a way, ripens the bodies, since it heats gently; Saturn cools and dries moderately. Ares dries at the utmost and burns, etc.

All the data are taken from the first book of Ptolemy's Tetabiblos (I.4), which gives a more accurate account for each wandering star, including causal explanations of their powers.

Hephaestion's use of textual sources shows clear similarities with the working method of medical compilers, such as Oribasius, mentioned above, or Paul of Aegina (seventh century CE). Hephaestion copied material from earlier authors, cutting and pasting passages from their works, which were often rephrased, abbreviated or paraphrased. ${ }^{45}$ He wanted to write a compilation that could be used as a reference work by practising astrologers, as Paul of Aegina's Medical Epitome (in seven books), for instance, served as a reference book for doctors. As Philip van der Eijk has pointed out, Paul interestingly 'compares his work to the kind of pocket-book legal synopses - what we could call a vademecum - that lawyers use for quick reference': ${ }^{46}$ this might recall the two legal enchiridia that Justinian's Digest (I 2.2) attributes to the second-century jurist Sextus Pomponius. ${ }^{47}$ Paul's medical compilation was never referred to as an encheiridion in late antiquity. However, it is worth mentioning that it did receive a similar label during the Renaissance. In 1538, the Swiss learned physician Alban Thorer (or Albanus Torinus, 1489-1550) published a full Latin translation of the Medical Epitome under the title Pauli

43 Papyri, on the contrary, had quite standard dimensions in term of roll height (nineteen to twenty-five centimetres in the Ptolemaic period; twenty-five to thirty-three in the Roman era). See Willian A. Johnson, 'The ancient book', in Roger S. Bagnall (ed.), The Oxford Handbook of Papyrology, Oxford: Oxford University Press, 2009, pp. 256-81, 263-5.

44 David Pingree, Hephaestionis Thebani apotelesmaticorum libri tres, Leipzig: Teubner, 1973, p. 1, 1. 5.

45 Miroslav Marcovich, 'Hephaestion, Apotelesmatica, Book I', Illinois Classical Studies (1976) 1, pp. 59-64; Paola

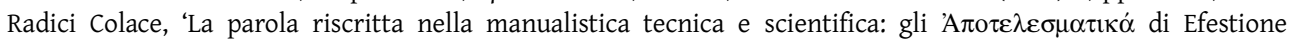
Tebano', in Sergio Sconocchia and Lucio Toneatto (eds.), Lingue tecniche del greco e del latino, vol. 2, Bologna: Pàtron, 1997, pp. 9-21.

46 Van der Eijk, op. cit. (38), pp. 534-5.

47 Broccia, op. cit. (11), pp. 31-2. 
Aeginetae medicinae totius enchiridion. ${ }^{48}$ In the preface, the translator praised Paul of Aegina, compendiosissimus medicinae scriptor ('the most concise medical writer'), for having provided the best possible summary of the medical art in all its parts.

\section{Alchemical handbooks}

In the sixteenth century various works on medicine were published under the title of enchiridia. An anonymous enchiridion medicinae, for instance, was printed in Paris in 1571: a short pharmacopeia (thirty-nine pages) mainly featuring lists of drugs, both simple medicines and ingredients for compound medicines. In 1573, the work was reprinted in Basel by Georg Henisch (1549-1618), who praised its conciseness in a freshly added preface: because of its very small size, scholars (studiosi) could easily look through the book and learn its content by heart. ${ }^{49}$

Unlike these early modern writings, late antique medical works were never labelled encheiridia. On the contrary, intriguing instances of the term encheiridion can be found in the alchemical works of Zosimus of Panopolis, active in Graeco-Roman Egypt between the third and the fourth centuries CE.

Heir of an earlier tradition including various pseudepigraphic works, Zosimus composed an extensive alchemical oeuvre whose textual tradition is as rich as it is entangled. ${ }^{50}$ Only an epitomized version of Zosimus' original Greek opus has been handed down by Byzantine manuscripts, where snippets of his authentic compositions have been excerpted and reorganized in sections that do not mirror their earliest organization. One can get a glimpse of the original structure of Zosimus' alchemical work by considering the twelve treatises preserved in Syriac translation, and handed down in a single manuscript that I am currently editing and translating into English (Cambridge University Library, MS Mm. 6.29, fifteenth century). ${ }^{51}$ These twelve treatises, or mimre in Syriac, are mainly collections of recipes organized around specific areas of expertise, such as the making of inks; the working of copper, tin or iron; and the like. ${ }^{52}$

Particularly relevant for our discussion is the work transmitted under the title Eighth Treatise (mimro) on the Making of Tin. Letter het [i.e. the eighth letter of the Syriac alphabet]. Book That Tells Us about Tin. Zosimus Warmly Greets the Queen Theosebeia. The treatise is dedicated to Zosimus' usual addressee, the rich woman Theosebeia - here even presented as a queen - who is often mentioned in the Greek excerpts as the dearest student of the Graeco-Egyptian alchemist. ${ }^{53}$ It mainly includes metallurgical recipes describing how to manipulate tin: the metal was 'purified', being mixed with alum, arsenic ores, soda, and other ingredients; it was superficially dyed with animal and vegetal substances (various kinds of bile, juices, etc.); it was melted with other metals, such as copper or lead (whose preliminary treatments are also described), in order to make coloured alloys.

48 Henry E. Sigerist, 'Albanus Torinus and the German edition of the "Epitome" of Vesalius', Bulletin of the History of Medicine (1943) 14, pp. 652-66, 656-7.

49 František Šimon, 'Enchiridion medicinae by Georg Henisch (1549-1618)', Ceská a Slovenská farmacie (2018) 67(2), pp. 85-90 (in Slovak); Martin Korenjak's bibliographical entry in the ERC project Noscemus database at https://wiki.uibk.ac.at/noscemus/Enchiridion_medicinae.

50 For a general overview see Michèle Mertens, Les alchimistes grecs IV.1. Zosime de Panopolis, Mémoires authentiques, Paris: Les Belle Lettres, 1995, pp. xx-cxii.

51 For a French translation of extensive sections of these Syriac books see Marcelin Berthelot and Rubens Duval, La chimie au Moyen-Âge, vol. 2, L'alchimie syriaque, Paris: Imprimerie nationale, 1893, pp. 210-66.

52 Matteo Martelli, 'L'alchimie en syriaque et l'oeuvre de Zosime', in Emilie Villey (ed.), Les sciences en syriaque, Paris: Geuthner, 2014, pp. 191-214.

53 Mertens, op. cit. (50), pp. xvii-xviii; Bink Hallum, 'Theosebeia', in Paul Keyser and Georgia Irby Massie (eds.), Encyclopedia of Ancient Natural Scientists, London and New York: Routledge, 2009, pp. 302-3. 
The opening section of the treatise provides a fascinating account of the origins of the first book of alchemy, which represents one of the most detailed versions of the legend of the revelation of alchemical secrets by fallen angels. This legend, already outlined in earlier alchemical works, deeply depends on the Enochian tradition and, in particular, on the so-called Book of the Watchers. The first book of alchemy - Zosimus explains was revealed to humankind by the fallen angels (simply called 'demons' in the text), who, after leaving Heaven and attracted by the beauty of women, passed on their secret knowledge to them. ${ }^{54}$ After setting the story in this mythological framework, Zosimus gives the following description of the foundational book that encapsulated all the teaching of the fallen angels (Mm. 6.29, fol. $49 \mathrm{v} 6-16):^{55}$

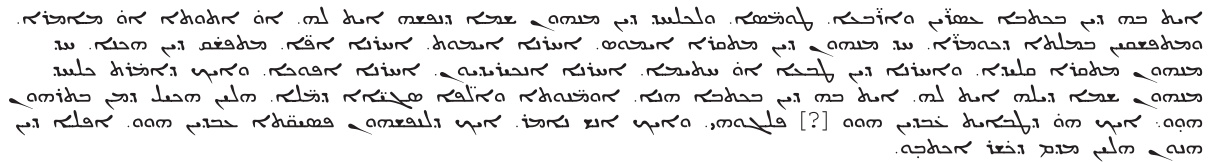

There are twenty-four tomes in this book [i.e. the revealed book on alchemy], and each of them is given a specific title, either a letter [of the alphabet] or a name. They are explained by the words of priests. One of these is entitled Imus, another Imut, another Face - so it was translated. One of these is entitled Key, another Seal or Signet, another Handbook [Syr. 'NKYRYDYWN=Gr. encheiridion], another Position [? Syr 'PWK' = Gr. epochēe. ${ }^{56}$ As I said, each one is given a specific title. This book contains the [alchemical] arts and many thousand words. Then, those who came afterwards, with the intent of doing well, divided the book in many parts; as someone would say, they did so in order to compose short versions [of the book] for themselves. But they were not even able to write something useful.

The revealed book of alchemy was composed of twenty-four sections or tomes, some of which were simply marked by a letter of the alphabet, others bearing more proper titles. Zosimus lists a few instances of the expressions used as headings: (1) the terms Imus and Imut, that are close to the Greek Imouth ('I $\mu \mathrm{ov \theta}$ ), perhaps an abbreviated form for Imhotep ('I $\mu$ ov $\theta n \varsigma$ ), the famous architect who served the mythical Egyptian pharaoh Djoser; ${ }^{57}$ (2) 'key', qlido in Syriac, which corresponds to the Greek kleis or kleidion ( $\kappa \lambda \varepsilon$ is or $\kappa \lambda \varepsilon 1 \delta i ́ o v) ;$ (3) 'seal' or 'signet', htimo in Syriac, which literally means 'what is sealed'; (4) 'handbook', namely the Syriac transcription of the Greek term encheiridion.

It is certainly difficult, if not impossible, to reconstruct the contents of an alchemical encheiridion, which was part of a larger, mythical book revealed by fallen angels. The twenty-four tomes that would have encapsulated this revelation remain part of a foundational myth of alchemy, whose reality goes beyond history. However, the alchemical art is,

54 Matteo Martelli, 'The alchemical art of dyeing: the fourfold division of alchemy and the Enochian tradition', in Sven Dupré (ed.), Laboratories of Art: Alchemy and Art Technology from Antiquity to the 18th Century, London and New York: Springer, 2014, pp. 1-22 (with further bibliography).

55 Berthelot and Duval, op. cit. (51), pp. 238-9.

56 Another possible interpretation is to read the Syriac term as the transcription of the Greek apokhe ( $\left.\dot{\alpha} \pi \mathrm{\chi} \chi \dot{\eta}^{\prime}\right)$, 'account, quittance'. The Byzantine tradition preserves a treatise by Zosimus under the title First Book of the Final

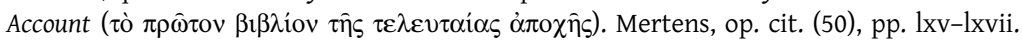

57 Mertens, op. cit. (50), pp. xcv-xcvi. We must note that, in his Chronography, the Byzantine historian Synkellos (eighth-ninth centuries CE) attributes a book entitled Imouth ('I $\mu$ ov' $\theta$ ) to Zosimus and cites it as the source for the account on the revelation of the fallen angels. Alden A. Mosshammer, Georgii Syncelli Ecloga chronographica, Leipzig: Teubner, 1984, p. 14. 
first of all, a written science, or at least is always presented as such by its practitioners. They identify themselves with the heirs of a long-established and distinguished tradition, which was traced back to mythical and wise founders. The teaching of these founders always takes a written form, being encapsulated in ancient books, whose contents and structure were to be interpreted and passed on over centuries.

In the above-mentioned passage, Zosimus complains that those who received the twenty-four tomes and their successors dispersed and abridged this knowledge. We must observe, however, that in other passages of his twelve treatises (mimre), Zosimus clearly refers to alchemical writings bearing the same titles as the twenty-four tomes of the original book of alchemy. For instance, in his tenth treatise, entitled The Tenth Letter on Lead, Letter yud (i.e. the tenth letter of the Syriac alphabet), Zosimus includes a recipe that explains how to produce gold-coloured silver. After giving the instructions, he specifies that similar treatments are to be found 'in the treatise [mimro] entitled Signet, and in the other [treatise entitled] Position, and also in the treatise entitled Key' (MS Mm. 6.29, fol. 71r14-16). ${ }^{58}$ The title Imout is also mentioned in many passages throughout Zosimus' twelve treatises: for instance, in his first mimro, he claims that all the practices described in the original books of alchemy are somehow encapsulated in the treatise entitled Imout (MS Mm. 6.29, fol. 17r5-6); ${ }^{59}$ in the seventh mimro, in a section devoted to the making of silver, he refers to the first and the second treatises of the Imout, which describe techniques for polishing bronze and producing metallic mirrors (MS Mm. 6.29, fol. 46v13-16). ${ }^{60}$

Along with these titles, the Encheiridion, too, is mentioned again by Zosimus in his twelfth Treatise on Electrum. ${ }^{61}$ After a long discussion on talismans, namely little metallic bottles (Syr. qulo, lit. 'pitcher') that Solomon himself would have described as powerful tools to capture demons, Zosimus refers to Jewish writings as the main sources for this topic. ${ }^{62}$ However, technical information on the nine ingredients used to produce the bottles and, in particular, the metallic alloy electrum they were made of, could be found in other writings as well (MS Mm. 6.29, fol. 88v13-19):

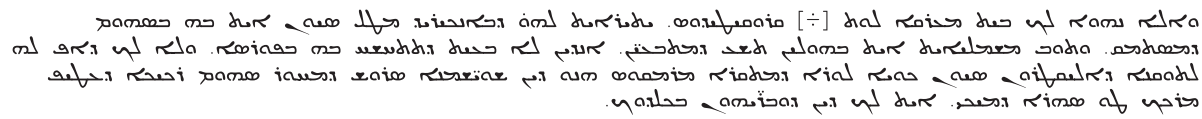

Otherwise, you will find refuge in the [? $]^{63}$ QRWQYTYDWS, especially in that which is in the Encheiridion [Syr. 'NKYRYD] about gold being [made] with iron that is coloured red. In these [books?] there is a full account of the nine [substances] that are necessary. If you do not want to use this means, you must also consider what is convenient for the making of the electrum: burnt gold, the silver that is called murmiqus

58 Berthelot and Duval, op. cit. (51), p. 254.

59 Berthelot and Duval, op. cit. (51), p. 214.

60 Berthelot and Duval, op. cit. (51), p. 235, also 250.

61 French translation in Berthelot and Duval, op. cit. (51), pp. 260-6. See also Alberto Camplani, 'Procedimenti magico-alchemici e discorso filosofico ermetico', in Giuliana Lanata (ed.), Il tardoantico alle soglie del Duemila: Diritto, religione, società, Genoa: ETS, 2008, pp. 73-98.

62 Berthelot and Duval, op. cit. (51), pp. 265-6. On this passage see Allegra Iafrate, 'Solomon, lord of the rings: fashioning the signet of power from Electrum to Nuhās', Al-Masāq: Journal of the Medieval Mediterranean (2016) 28(3), pp. 221-41.

63 Here, in the manuscript, there is a sign (a short horizontal stroke with two dots above) which might mark a lacuna to be filled with a marginal note (that seems to be missing). 


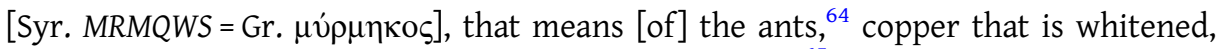
tender iron that is softened again, lead, purified silver. ${ }^{65}$

Zosimus seems to consider a work entitled encheiridion as a relevant source on the ingredients - i.e. the nine substances he already mentioned in the previous part of the treatise - and the procedures necessary for the making of electrum. Less clear is his reference to the QRWQYTYDWS, almost certainly the transcription of a Greek term, which is, however, difficult to reconstruct and interpret. ${ }^{66}$ Regardless of this opacity, Zosimus seems to give a kind of summary of what one would have found in the quoted sources and lists different metals that, after undergoing various treatments, take specific physical characteristics in terms of colour, hardness or purity. A few recipes on how to treat some of these metals are collected in the following and last part of Zosimus' treatise (MS Mm. 6.29, fols. 89 r-90r).

At this point, one might wonder whether Zosimus, in the passages mentioned above, was actually referring to some books he had access to, books that bore the same titles as the alchemical tomes revealed by the fallen angels. If we consider the tendency of ancient alchemical literature towards pseudepigraphy, in particular the attribution of many writings to remote figures (such as Moses, Ostanes or Democritus), we cannot rule out the possibility that, in Zosimus' day, alchemical books with similar titles circulated in Egypt under the names of the mythical founders of the alchemical art. Various Byzantine alchemical authors mention a book entitled Kleidion ( $\kappa \lambda \varepsilon i \delta i o v)$, 'the little key', or Kleis ( $\kappa \lambda \varepsilon i \varsigma)$, 'key', attributed to Hermes Trismegistus. According to the alchemist Christianos (seventh-eighth centuries CE), in this book Hermes would have dealt with the so-called komaris, an unidentified substance mentioned in recipes for purple dyeing; ${ }^{67}$ Stephanos of Alexandria (seventh century CE) claims that Hermes explained how to treat the stone etesios (unidentified) with copper and oil in his Little Key. ${ }^{68}$ The same title was probably used to introduce the Greek recipe book that, translated into Latin, is known as Mappae clavicula, one of the most famous and successful medieval collections of alchemical recipes. ${ }^{69}$ The term clavicula, indeed, seems to correspond to the Greek kleidion: according to its preface, this collection of recipes (compositio) was meant to provide the 'key' to unlock the instructions found in the ancient 'sacred books', presumably the alchemical books of the ancients. ${ }^{70}$

After the seminal study of Robert Halleux and Paul Meyvaert, ${ }^{71}$ scholars generally agree that this collection of almost two hundred recipes must be identified with an early Latin translation of a (now lost) Greek original corpus perhaps entitled Kleidion

64 A precious stone called myrmēkitis is mentioned by Pliny the Elder, Natural History, 37.187.

65 We must note that the names of the metals used in this context are quite typical of the alchemical lexicon; a similar list also appears at the beginning of the second treatise by Zosimus (MS Mm. 6.29, fol. 30v). See Berthelot and Duval, op. cit. (51), p. 221; Rubens Duval, 'Notes de lexicographie syriaque et arabe', Journal asiatique, series 9 (1893) 2, pp. 290-361.

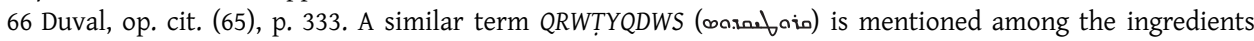
used to produce the electrum at the beginning of the treatise: see Berthelot and Duval, op. cit. (51), pp. 260-1.

67 See, e.g., Marcelin Berthelot and Charles-Emile Ruelle, Collection des anciens alchimistes grecs, 3 vols., Paris: Georges Steinheil, 1887-8, vol. 2, p. 277.

68 Stephanos of Alexandria, Lecture III, 137-40, in Maria K. Papathanassiou, Stephanos von Alexandria und sein alchemistisches Werk, Athens: Cosmosware, 2017, p. 172.

69 Edition and translation in Sandro Baroni, Giuseppe Pizzigoni and Paola Travaglio, Mappae clavicula: Alle origini dell'alchimia in Occidente: Testo - Traduzione - Note, Saonara: Il prato, 2013.

70 Baroni, Pizzigoni and Travaglio, op. cit. (69), pp. 58-9.

71 Robert Halleux and Paul Meyvaert, 'Les origines de la Mappae clavicula', Archives d'histoire doctrinale et littéraire du Moyen Âge (1987) 54, pp. 7-58. 


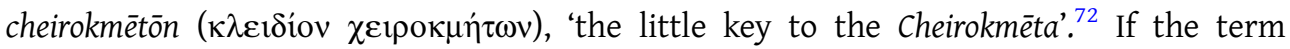
clavicula is usually interpreted as the translation of the Greek kleidion, 'litte key', more enigmatic is the second term, mappa, lit. 'cloth, towel, napkin', which does not sound very apt for an alchemical book. In order to cope with this difficulty, Halleux and Meyvaert proposed an intriguing and successful explanation: the Latin translator of the original recipe book, being not well versed in Greek, would have misunderstood the dif-

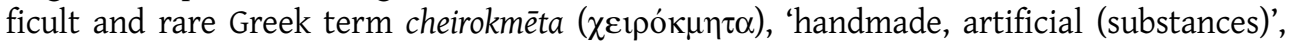
and read, instead, cheiromaktron ( $\chi \varepsilon$ ıó $\mu \alpha \kappa \tau \rho o v)$, a more common Greek term for 'cloth, towel, napkin'. Various Latin-Greek glosses confirm that the term mappa could correspond to the Greek cheiromaktron. ${ }^{73}$ Moreover, according to the tenth-century lexicon Suda ( $\zeta 168$ Adler), Zosimus' alchemical books circulated under the title of cheirokmetta, thus confirming the use of the term as book title.

Another explanation is, however, possible, especially if one considers the passages of Zosimus' treatises discussed above, where the term encheiridion stands for the title of a foundational book of alchemy. The Greek term encheiridion, in fact, was not only used in reference to books in early Byzantine times. Next to 'handbook', the term could also mean 'towel, cloth', as clearly emerges from hagiographical literature. ${ }^{74}$ For instance, in the seventh-century Life of Saint Theodore of Sykeon (\$77), the Holy Mary is said to have taken three pills out of her napkin (encheiridion) in order to heal the saint who fell ill after being poisoned; ${ }^{75}$ according to the Life of the Saint Andrew the Fool (seventh-tenth centuries (E), an angel took some seasoning out of a handkerchief (encheiridion) while cooking a soup for Epiphanios. ${ }^{76}$ The translator of the Greek alchemical recipe book at the basis of the Mappae clavicula, presumably a Christian scholar well educated in the sacred scriptures, was probably familiar with this meaning of encheiridion. Therefore he might have

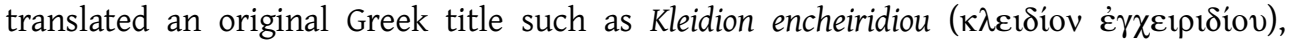
'the little key to the (alchemical) handbook', with the expression Mappae clavicula, where mappa would have been a literal translation of encheiridion in its meaning of 'cloth, towel'. We can observe that the Pope Zacharias (741-52 CE) actually rendered the accusative mappulas with the Greek encheiridia in his translation of Gregory the Great's Dialogues (Book 2, Chapter 19). ${ }^{77}$ If this hypothesis is correct, the Mappae clavicula would represent the Latin translation of a Greek alchemical recipe book that circulated in late antiquity with a title including the term encheiridion.

\section{Collecting and legitimizing alchemical recipes}

The use of the term encheiridion to mark recipe books circulating in Graeco-Roman Egypt is confirmed by Zosimus' twelve treatises preserved in Syriac translation. Moreover, scholars have observed that various recipes of the Mappae clavicula present striking similarities

72 Halleux and Meyvaert, op. cit. (71), p. 13; Baroni, Pizzigoni and Travaglio, op. cit. (69), pp. $27-8$.

73 See, for instance, George Goetz, Corpus glossariorum latinorum, vol. 6, fasc. 1, Thesaurus glossarum emendatarum, Leipzig: Teubner, 1899, p. 680.

74 See, for instance, Erich Trapp, Lexikon für byzantinischen Gräzität, besonders des 9-12 Jahrhunderts, 2 vols.,

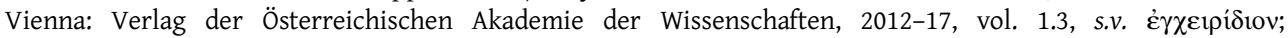
Evangelinos A. Sophocles, Greek Lexicon of the Roman and Byzantine Periods (from B.C. 146 to A.D. 1100), New York: Charles Scribner's Sons, 1900, p. 419.

75 Edition in André-Jean Festugière, Vie de Théodore de Sykeôn, Brussels: Société des Bollandistes, 1970.

76 Lennart Rydén, The Life of St Andrew the Fool, vol. 2, Text, Translation, and Notes, Uppsala: Acta Universitatis Upsaliensis, 1995, pp. 77-8.

77 See Charles Du Cange et al., Glossarium mediae et infimae latinitatis, éd. augm., 10 vols., Niort: L. Favre, 1883-7, vol. 5, col. 255. 
with some recipes included in the twelve Syriac books. ${ }^{78}$ For instance, the same technique to make silver blue like a sapphire is textualized in very similar forms in the Latin recipe book and in the first book of Zosimus:

Mappae clavicula 91: Argenti color sapphirinus. Nitrum rufum et alumen simul confla. Deinde tere cum aqua, unge argentum et calefac. ${ }^{79}$

Sapphire dye of silver. Melt red soda and alum together; then grind them with water, rub on silver, and heat up.

Zosimus' first book (Mm. 6.29, fol. 16v11-13)

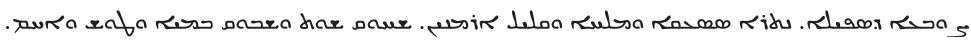

Sapphire dye. Red soda, alum and a bit of ammoniac [salt]; grind together, leave it in water, rub it on [scil. the metallic leaf] and heat up.

Both recipes describe how to prepare a mixture that, when rubbed on silver, dyes it superficially. Zosimus' text does not specify the metal to be treated, since the recipe is included in a section devoted to the dyeing of silver.

Only a close and thorough comparison between the two collections of recipes will fully elucidate their possible relations. At this stage, any attempt to identify the encheiridion mentioned by Zosimus with the Greek text behind the Mappae clavicula would be speculative and risky, since it could oversimplify a fluid and diversified tradition. Many recipes included in both Zosimus' twelve treatises and the Mappae clavicula overlap with a wider set of alchemical compilations, in particular with the so-called Leiden and Stockholm papyri, two anonymous recipe books on papyrus codices written in third- or fourthcentury Egypt. ${ }^{80}$ These two papyri, which include more than two hundred recipes on various topics (how to dye, soften or harden metals; how to produce silver- and gold-coloured alloys; how to make inks and fake precious stones; how to dye wool purple), have been variously linked to workshop practices. They were defined either as handbooks for ancient craftspeople (e.g. goldsmiths or dyers) or as copies of the workshop notes of an artisan. The lack of stains or signs of damage in the two codices has led some scholars to identify them with copies for a library. However, as recently argued, they might have been handled only by a supervisor or they could simply draw on earlier workshop copies. ${ }^{81}$

The structure of these alchemical recipe books is quite flexible, and the number of recipes included can easily vary. This flexibility could certainly make it easy to update, expand or reduce a given collection by adding or leaving out a set of recipes. ${ }^{82}$ On the other hand, each alchemical recipe book could be potentially incomplete and fail to provide an exhaustive summary of the most relevant procedures of the art. Probably in order

78 Baroni, Pizzigoni and Travaglio, op. cit. (69), pp. 237-42.

79 Baroni, Pizzigoni and Travaglio, op. cit. (69), p. 138.

80 Robert Halleux, Les alchimistes grecs I. Papyrus de Leyde, papyrus de Stockholm, recettes, Paris: Les Belles Lettres, 1981. In his commentary on the texts, Halleux highlights many similarities with the Syriac books of Zosimus and the Mappae clavicula. See also Baroni, Pizzigoni and Travaglio, op. cit. (69), pp. 219-36.

81 Mark Clarke, 'The earliest technical recipes: Assyrian recipes, Greek chemical treatises and the Mappae Clavicula text family', in Ricardo Córdoba (ed.), Craft Treatises and Handbooks: The Dissemination of Technical Knowledge in the Middle Ages, Turnhout: Brepols, 2013, pp. 9-32.

82 A practice well documented in the so-called Michigan Medical Codex, a recipe book identified as a manual for a practising physician; see Louise C. Yountie, P. Michigan XVII, the Michigan Medical Codex (P. Mich. $758=$ P. Mich. Inv. 21), ed. Ann Hanson, Atlanta: Scholars Press, 1996. 
to cope with this risk, Zosimus of Panopolis anchored the alchemical encheiridion he used in his treatises to the original revelation of alchemy: in this way, the alchemical handbook was presented as authoritative and complete, being part of the foundational teaching of the fallen angels, before it came to be dispersed and summarized.

The effort to go back to the original book of alchemy is evident in Zosimus' treatises as well, since the alchemist seems to have marked them with the same titles given to the twenty-four tomes that composed the revealed book. Indeed, these tomes, as described by Zosimus in the passage quoted above, present striking similarities to the structure of his own alchemical writings. First of all, each of the original tomes was marked by a letter of the alphabet. Zosimus refers to his own books by using letters of the alphabet, for instance when he mentions his Book on the Letter Kappa and his Book on the Letter Omega. ${ }^{83}$ Moreover, the Byzantine alchemist Christianos quotes Zosimus' Book on the Letter Sigma, ${ }^{84}$ while the tenth-century lexicon Suda ( $\zeta 168$ Adler) ascribes to him twenty-eight alchemical books arranged in alphabetical order. The reference to the alphabetical arrangement is usually interpreted as an indication of the use of letters as book titles. $^{85}$

The Syriac tradition confirms these data. There again, many of Zosimus' twelve treatises include a letter of the alphabet in their title. ${ }^{86}$ More importantly, some of these treatises are also marked by terms that correspond to the titles attributed by the alchemist to the twenty-four tomes revealed by the fallen angels. In particular, Zosimus' Seventh Treatise is also entitled Signet (lit. 'what is sealed') or Seal (Mm. 6.29, fol. 45r), while the Ninth Treatise on the Letter Tet is also called 'the key [qlido] of everything' (Mm. 6.29, fol. 55r). ${ }^{87}$ This ninth treatise is mainly devoted to mercury and insists on both its volatility and its promptness in being 'fixed' (i.e. solidified) when mixed with other substances. Interestingly, the Byzantine alchemist Christianos also attributes a Book of the Keys (biblos kleidōn) to Zosimus while discussing the capacity of mercury to be attracted by other natures (i.e. natural bodies). ${ }^{88}$

In conclusion, Zosimus seems to construe his own alchemical treatises by mirroring the structure he attributed to the original twenty-four alchemical tomes that the fallen angels revealed to humankind. The encheiridion was one of these tomes whose authority and knowledge Zosimus tried to recover and re-encapsulate in his treatises. After all, the strong continuity between the books of the ancients and Zosimus' own alchemical writings is stressed by the alchemist himself in a section devoted to the preparation of alchemical 'waters' (Mm. 6.29, fols. 64v15-19): ${ }^{89}$

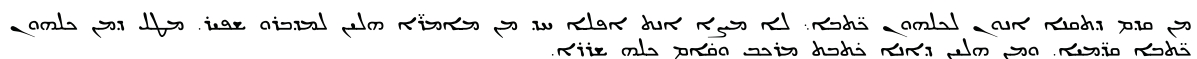

Before getting all the books, you won't be able to properly carry out even a single [operation] from these treatises [mimre], because a sound knowledge arises and derives from all the ancient books as well as from those books that I wrote.

83 Berthelot and Ruelle, op. cit. (67), vol. 2, p. 246. We must observe that Zosimus' book On the Letter Omega is preserved by the Byzantine tradition. See Mertens, op. cit. (50), pp. 1-10.

84 Berthelot and Ruelle, op. cit. (67), vol. 2, p. 274.

85 Needless to say, the Greek alphabet only includes twenty-four letters. Zosimus might have marked some books with a letter and others with a proper title. See Mertens, op. cit. (50), pp. xcvii-ci.

86 One can add the following titles to the treatises already mentioned: (1) Beginning of the Treatise on the Making of Copper: Letter Waw; (2) Treatise on Iron: Letter Koph (etc.); see Martelli, op. cit. (52), pp. 201-3.

87 Berthelot and Duval, op. cit. (51), pp. 232, 242.

88 Berthelot and Ruelle, op. cit. (67), p. 277.

89 Berthelot and Duval, op. cit. (51), p. 250. 
In order to fully understand the procedures to be carried out, the ancient alchemist was expected to master a polyphonic textual tradition, which could not lose its connection to the original 'revelation' of the art. Alchemical encheiridia were certainly part of this revelation. However, rather than representing the summary of larger works, as was the case for many handbooks discussed above, these encheiridia became the sources of Zosimus' larger, more comprehensive account of the alchemical art.

\section{Concluding remarks}

To conclude, we can observe that most ancient encheiridia share a didactic purpose and their use can be better understood in the context of Graeco-Roman and late antique schools. For instance, Hephaestion's and Domninus' encheiridia are short, well-organized catalogues of basic notions, neatly textualized into concise definitions (along with relevant examples), which can be easily located in the booklets and memorized by students taking classes on mathematics or grammar.

The fallen angels take over from masters of grammar or philosophy in the Enochian myth that Zosimus reframed in his treatises: the revealed knowledge is condensed in a foundational book, which also includes an alchemical encheiridion. This original book represents the authoritative source of the purest and most reliable alchemical teaching that later alchemists were expected to carefully preserve and properly understand. Zosimus' technical writings, along with other late antique recipe books (including, perhaps, the Greek text behind the Mappae clavicula), tapped into that authority. In a way, an alchemical recipe book is a list of discrete textual units that might be assimilated in its structure to the encheiridia pertaining to other areas of expertise. Each recipe is a 'small unit whose meaning does not depend on adjacent units', and it potentially encapsulates all the necessary instructions to carry out a single alchemical procedure. Likewise, each definition of metres in Hephaestion's Handbook, for instance, or each ethical maxim in Rufinus' translation of the Sentences of Sextus, could be used individually by the readers of these books. However, the connection of each textual unit to its context, to what follows or precedes, can be very loose in collections of recipes, while it seems tighter in those encheiridia that aim at providing the basic elements of a given discipline.

The earliest extant definition of encheiridion goes back to Heliodorus (first century CE). In his Prolegomena to Hephaestion's handbook on metres, Longinus quotes the first lines of Heliodorus' (lost) work on the same subject:

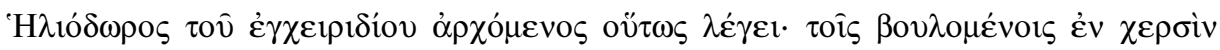

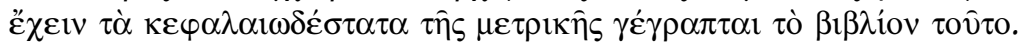

Heliodorus opened his encheiridion by saying: 'this book has been written for those who want to have the most capital points of the metric art in their hands'. ${ }^{11}$

The same emphasis on capital points (kephalaia) emerges in Nicomachus' preface to his Handbook on Harmonics. These writings served as primers, from which students of music or grammar could learn those basic notions that were further explained by their teachers in

90 Laurence Totelin, Hippocratic Recipes: Oral and Written Transmission of Pharmacological Knowledge in Fifth- and Fourth-Century Greece, Leiden and Boston: Brill, 2009, p. 61 (with further bibliography). This structural analysis draws on Michael Hoey's concept of 'text-colony', which has also been applied to the study of medieval technical writings. See Giulia Brun, 'The transmission and circulation of practical nowledge on art and architecture in the Middle Ages', PhD thesis, Milan (Politecnico), 2015, pp. 185-208.

91 Consbruch, op. cit. (31), p. 86. 
classrooms and in more comprehensive textbooks (or isagogic treatises). Likewise, Domninus' and Arrian's handbooks were mainly addressed to students of mathematics and Stoic philosophy. Ancient encheiridia also collected ethical and religious precepts, key rules condensed in small booklets that their readers could carry along: thus they could always go back to these books as guides in their daily life. A certain tension between brevity and comprehensiveness emerges when the author of an echeiridion had to deal with a rich and complex tradition. In order to properly summarize the most authoritative astrological writings of earlier authors, Hephaestion of Thebes composed a three-book handbook: it actually functioned as a reference book in a way similar to an almost contemporary medical encyclopedia by which Hephaestion was perhaps influenced to a certain extent. Alchemical encheiridia, on the other hand, were situated at the origin of the tradition they were said to encapsulate: they represented foundational writings that any practitioner was expected to have always at hand, in order to gain direct access to the original teaching revealed by the mythical founders of the alchemical art.

Acknowledgements. This publication is part of the Alchemy in the Making: From Ancient Babylonia via Graeco-Roman Egypt into the Byzantine, Syriac, and Arabic Traditions (AlchemEast) research project. The AlchemEast project has received funding from the European Research Council (ERC) under the European Union's Horizon 2020 research and innovation programme (G.A. 724914). I also would like to thank the anonymous peer reviewers for their precious remarks and suggestions.

Cite this article: Martelli M (2020). Ancient handbooks and Graeco-Egyptian collections of alchemical recipes. BJHS Themes 5, 39-55. https://doi.org/10.1017/bjt.2020.4 